\title{
EDITORIAL
}

\section{RBP and Brazilian science}

\author{
Flavio Kapczinski \\ Editor-in-Chief, Revista Brasileira de Psiquiatria.
}

We have received with great satisfaction and enthusiasm the news about our latest impact factor in Thomson Reuters Journal Citation Reports (JCR). The 2012 impact factor of 1.856 represents an increase of $55 \%$ over the previous year, and places RBP as the Brazilian journal with the highest impact factor among all scientific publications in the country in any field of knowledge.

The impact factor measures the frequency with which the average article in a journal is cited in the two years following its publication; it is one of the most influential indexes used to evaluate scientific journals worldwide, providing an objective tool to compare the influence of different journals within a discipline area. The steady growth of our impact factor over the years ${ }^{1-3}$ highlights the increasing visibility of the articles published in RBP and the high reputation the journal holds in the scientific community.

This leading position is the end result of the dedicated work and commitment of several eminent psychiatrists who over the years have spared no efforts to promote the excellence of our journal. The high standards and the rigorous scientific polices set by previous editors have been determinant to this success.

As we move forward, we aim at further increasing our editorial quality, international visibility, and strict adherence to ethical regulations. We are also working hard to speed up the publication process by providing early online access to articles ahead of print. We are sincerely grateful to the Brazilian Psychiatric Association (Associação Brasileira de Psiquiatria, ABP), to all authors, reviewers, and editors whose contributions to RBP have helped to improve even more the level of excellence in our field.

\section{References}

1 Bressan RA, Mari JJ, Mercadante M, Hoexter MQ, Lafer B, Miguel $\mathrm{EC}$, et al. RBP is the Latin American medical journal with the highest impact factor. Rev Bras Psiquiatr. 2008;30:179-82.

2 Lafer B, Fleck MP, Kieling C, Polanczyk GV, Tavares H, Fontenelle LF, et al. RBP increases its impact factor. Rev Bras Psiquiatr. 2009;31:196.

3 Crippa JA, Bressan RA, Salum GA, Quevedo J, Kieling C, Hoexter $M Q$, et al. RBP increases its impact factor again and is progressively more cited in other journals. Rev Bras Psiquiatr. 2011;33:218. 